\title{
LISTENING ANXIETY AMONG INDONESIAN EFL STUDENTS
}

\author{
Vina Agustiana \\ Department of English Education, Faculty of Teachers Training and Education, \\ Universitas Kuningan, Indonesia \\ Email: v.agustiana08@gmail.com
}

APA Citation: Agustiana, V. (2018). Listening anxiety among Indonesian EFL students. Indonesian EFL Journal, 5(1), 13-26. doi: 10.25134/ieflj.v5i1.1607.

Published: 01-01-2019

\begin{abstract}
Listening skill is essential in EFL learning. Experiencing more than three years in teaching Listening, the researcher covers that EFL students face problems in comprehending what people say in target language. Through this study, the researcher aims at exploring EFL students' experience in learning to listen to spoken English text which covers (a) students' attitude towards learning to listen to spoken English texts, b) listening anxiety in listening to spoken English texts, and (c) students' effort in improving their listening skill in listening to spoken English text. To meet the research objectives, the researcher used a quantitative research through applying a survey design. A closed ended questionnaire containing 50 questions were distributed to $58 \mathrm{EFL}$ students of a Private University in West Java, Indonesia. The questionnaire was tested its validity and reliability. Moreover, the data were analyzed descriptive statistically. Data revealed that students show (a) a positive attitude towards learning to listen to English spoken text (3.56); (b) students' listening anxiety is in high level (3.52); and (c) students have a high effort in improving their listening skill (3.74). To conclude with, in spite of the high level of students' listening anxiety, they show the high level of attitude in learning to listen to English spoken text and the high effort in improving their listening skill as well.
\end{abstract}

Keywords: attitude; listening anxiety; listening skill.

\section{INTRODUCTION}

Listening skill is essential in EFL learning. It has, indeed, an important role in the communication process (Gilakjani \& Ahmadi, 2011). This is because the primary key in the acquisition of a language is to understand the information received as input. Relation to listening skills, input received is in the form of spoken language. Rost (2002) states that listening activities are vital in the language class because the class provides input for the students. This is in line with Hamouda (2013) who states that listening skill is very important in acquiring understandable input. Thus, language acquisition occurs when a person understands the input received, and the listening skill is a key component affecting the input understanding process.

Variety of listening is divided into two, namely extensive and intensive listening.
Extensive listening is emphasized in listening activities more freely and more generally, while the intensive listening is directed at a much more controlled activity on a particular subject (Harmer, 2001). The way people listening to, either extensive or intensive listening may influence people's ability in comprehending the message taken from the spoken language.

There are various factors that become obstacles in the process of achieving listening comprehension. Obstacles in listening are defined as external and internal characteristics that may affect the understanding of an oral text relating to cognitive procedures at each stage of listening comprehension (Goh, 2000). Hermawan (2012, p. 49-54) describes that motivation, hearing problem, physical condition, and limitation of self in 
maintaining focus of thinking belong to internal factor, while material, environment, speaker, style and speech technique are external factors that hinder the success listening.

In teaching English skills in Indonesia, listening is one of the skills that are considered difficult but neglected (Adnan, 2012). In fact, listening skills are one of the basic skills of language, so teaching listening skills deserve the same priority as other basic language skills, i.e. reading, speaking, and writing. Hasan (2000) states listening comprehension is an appropriate effort in the acquisition of language and in the effort to improve the ability of other languages. Thus, it can be said that listening skill is not only related to the ability to accept input, but also related to the development of language skills, especially the speaking skill. This is in line with Rost (2002) who states that the development of skills in listening is the key to getting the speaking skill.

According to Hamouda (2013), listening and speaking skills are not significant parts of many books and teachers do not consider these skills in their classes. Osada (2004) states that listening is not very important for both teachers and learners and teachers test not to teach listening and learners learn listening not listening comprehension. Given the importance of listening in foreign language learning, it is precisely that teaching listening comprehension tends to be ignored in various EFL programs. This is certainly one of the problems faced by students who learn a foreign language (EFL learners) in improving the understanding of listening. EFL learners have crucial problems in listening comprehension because universities pay attention to grammar, reading, and vocabulary (Hamouda, 2013). This neglect is the result of the debate over which language skills are the most important in learning foreign language acquisition. In addition, most teachers assume that the listening activity is a spontaneous activity as well as breathing activity (Thomas \& Dyer, 2007). In the classroom, teachers tend to assess listening skills, not teaching listening, while students tend to learn to listen instead of listening comprehensively (Hamouda, 2013). Based on this, in an effort to improve the comprehension of listening, teachers should understand the difficulties experienced by students in listening first. Thus, teachers are able to create strategies to help students solve the difficulties they experience in listening.

Based on the experience of the writer who has taught listening courses to the English Department students for more than three years, the author concludes that students who learn a foreign language experience many obstacles in the effort to understand the spoken language spoken by native speakers. This is based on the final test results in each semester in the listening courses which indicate that students' listening skills are at low levels. This is also experienced by several other researchers, such as Hayati (2010), Muljanto (2012), and Hamouda (2013). This is also in line with Goh (2000) who argues that students have difficulty in identifying familiar words, whereas students know the words but they find it difficult to understand the meaning of the words.

Based on this, the author would like to express the experience of the Indonesian EFL students which includes (a) students' attitude towards learning to listen to spoken English texts, b) listening anxiety in listening to spoken English texts, and (c) students' effort in improving their listening skill in listening to spoken English text.

\section{METHOD}

This research used quantitative research method through applying survey research design. Sugiyono (2012, p. 8) states that "quantitative method is a research method based on positivism philosophy, used to examine in a particular population or sample, data collection using research instruments, quantitative/statistical data analysis, with the aim to test the hypothesis has been established". Meanwhile, survey research design is a design in which 
researchers describe quantitatively the trends, attitudes, or opinions of a particular population by examining the sample of the population (Cresswell, 2014). This study used a questionnaire in data collection, with the aim of generalizing populations based on predetermined samples (Babbie, 1990, in Cresswell, 2014). The questionnaires used include statements about difficulties and difficulty factors in the comprehensive listening experienced by Indonesian EFL students.

This research involves 58 second semester students of English Department in a private University in Indonesia. The selection of respondents of this study is based on two reasons. First, the author is one of the teachers in the study program. Obviously, this can help the authors to get easy access to the research site. Second, the result of the students' final test in listening course which indicate that students' listening skills are at low levels. Therefore, the author tends to cover the students' problem in learning to listening.

Questionnaire is the main instrument in this research. Questionnaires are used to collect data in the form of phenomena that are not directly observed, such as experience, opinions, values, interests, etc. (Gall, Borg \& Gall, 2003). Of course, this questionnaire is used to collect specific data about the student's experience in learning listening comprehension. The questionnaire is used to explore the EFL students' learning experiences in learning to listening to spoken English text which includes: (a) students' attitude towards learning to listen to spoken English texts, b) listening anxiety in listening to spoken English texts, and (c) students' effort in improving their listening skill in listening to spoken English text. In this case, all respondents filled out one of the answer options based on the statement provided according to what they felt. The distribution of questionnaires was carried out at the last meeting in the listening for academic purposes courses conducted in the second semester. The authors assume that after students have a 2-semesters learning to listening experience, students will provide more accurate data on what factors are their obstacles in listening to the comprehensive English oral test.

The questionnaire is Likert-Scale consisting of 50 statements that are divided into three themes, namely (a) attitudes of students learning to listen to spoken English texts, (b) difficulties faced by students related to listening comprehension, and (c) students' effort in improving listening skills of spoken English text. The first theme consists of six statements divided into two topics, namely (1) students' attitudes toward the importance of listening to spoken English texts, and (2) the attitude of students to the difficulty in listening to spoken English texts. The second theme consists of 38 statements divided into two topics, namely (1) internal issues that include (a) the material, (b) language, (c) concentration, (d) psychological aspects, and (e) student listening skills, (2) external issues that include (a) the speaker, and (b) the physical or environmental aspects. While the third theme consists of six statements that are divided into two topics, namely the efforts of students conducted (1) inside the campus and (2) outside the campus environment.

There are 5 scales on each statement in the questionnaire. However, the choice of scale is tailored to the research objectives, where the choice of scale in each statement on theme 1 and theme 2 has that (SA) strongly agree, (A) agree, $(\mathrm{N})$ neutral, (DA) disagree, and (SDA) disagree. On theme 3, the scaling options include always (A), often $(\mathrm{O})$, sometimes $(\mathrm{S})$, rarely $(\mathrm{R})$ and never $(\mathrm{N})$. Each questionnaire item is arranged based on three aspects, namely affective, behavioral, and cognitive (Oskamp \& Schultz, 2005). This questionnaire was adapted from Hamouda (2013).

The questionnaire was analyzed statistically descriptively. Descriptive statistics are used to infer data (Malik \& Hamied, 2014). Before the questionnaire is calculated, the questionnaires were sorted. If each item is not filled, then the questionnaire would not be used. This is done to avoid 
invalid data. Questionnaires have been through the feasibility test by using the validity and reliability test. The concurrent and convergent validity of the questionnaire has been tested through factor analysis, and it is found that the validity is already within a reasonable level (eligible). Reliability of factors has also been tested through alpha coefficient and it is known that reliable research instruments with strong level.

\section{RESULTS AND DISCUSSION}

Students' attitude towards learning to listen to spoken English texts

This section describes the research data relating to the difficulties of Indonesian EFL students in learning to listening which is divided into three parts. Based on the results of data analysis on questionnaire presented in Diagram 1, it can be seen that the attitude of students in learning to listening to spoken English text (theme 1) is at a high level with the average of 3.46. Even so with the difficulties faced by students in learning to listening to spoken English text (theme 2) which is at a high level in which the average score is 3.52. In addition, it is also known that the efforts of students in improving their listening skill to listening to spoken English text (theme 3 ) are also at a high level with a mean of 3.74. This suggests that although students perceive that the difficulty in comprehending comprehension is high; students continue to address these lessons well as well as the high effort of the students to improve the comprehension of comprehensive English-language oral texts.

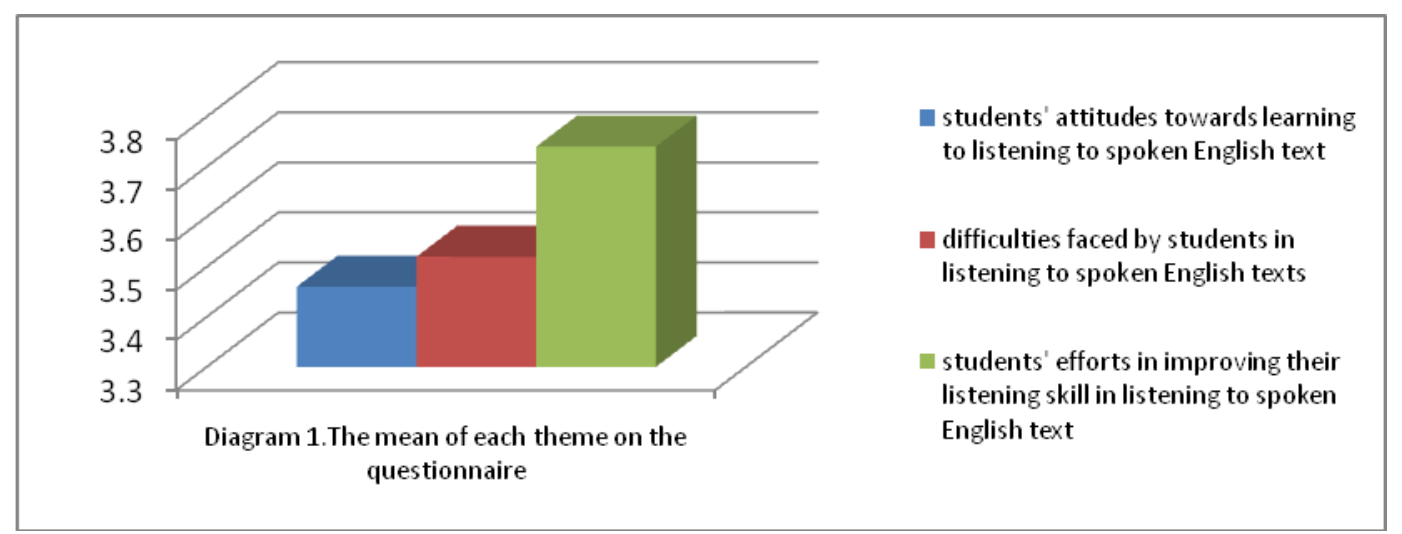

Diagram 1. The mean of each theme on the questionnaire

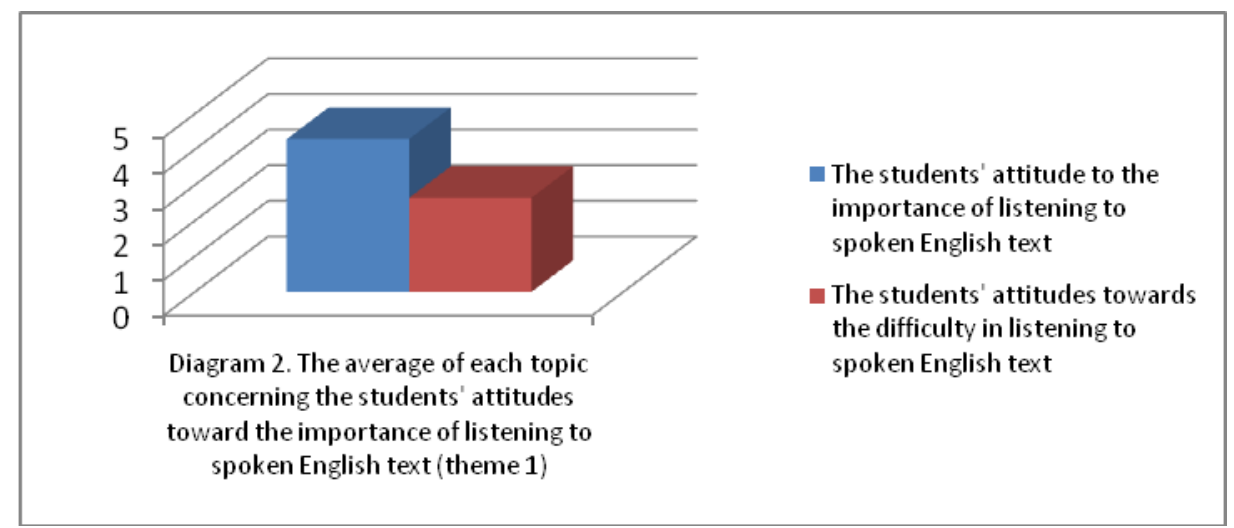

Diagram 2. The average of each item on theme 1

Based on Diagram 2, it can be seen that the students showed a very high attitude towards the importance of listening to spoken English text (topic 1 on theme 1) where the average was at 4.29 , and the students showed a normal attitude to the difficulty in learning to listening to spoken English text (topic 1 on theme 1) where the average is at 2.64. The identification of students' attitudes toward the importance of 
listening to spoken English text is divided into two topics.

The first topic is the students' attitude toward the importance of listening to spoken English text which is at very high level with the average of 4.29 reflected in three aspects of attitude, that is affective, behavior, and cognitive. Based on the existing data, students thought that listening comprehension was important to be studied (4.46), so they were happy (4.46) and would learn a listening comprehension of spoken English texts (4.14) to improve their listening skills. Thus, students also agree with some experts who say that listening is important to learn. Among them is Adnan (2012) which states that the teaching of listening skills so as not to be neglected. In addition, Wallace, Hand, and Prain (2004) argue that listening skills are a very important skill because these skills make a person gain insight, definition, knowledge, and information, and achieve success in communicating with others.

Of course, there are several reasons why listening is important, including in which facts suggest that students receive $90 \%$ of information in school from listening from both teachers and from others (Schwartz, 2004, cited in Adnan, 2012). This is in line with Rost (2002) who states that listening activities are vital in the language class because the class provides input for the students. Furthermore, Jafari and Hashim (2015) add that listening is a channel for comprehensible input and more than 50 percent of the time learners spend in learning a foreign language is devoted to listening. Given that listening is related to oral communication that aims to obtain information and understand the content of information, so that information obtained from listening activities is the basis for developing other language skills. Therefore, listening skill is one of the language skills that must be mastered properly in order to improve the acquisition of other language skills (Hasan, 2000).

Relation to feelings of pleasure and desire of students to follow learning listening, it certainly illustrates the motivation from within the students themselves to improve their listening skills through learning listening. With the motivation, students will listen more effectively, and consciously select what is being heard especially when the need or want the information (Hermawan, 2012). In addition, the lack of motivation in listening can be difficult in listening (Wilson, 2008). Thus, the high motivation in students is expected to reduce the difficulties faced them in listening.

The second topic is the attitude of students to the difficulty in listening to spoken English text in normal level with the mean of 2.64. This topic is reflected in three aspects of attitude, namely affective, behavioral, and cognitive. Students' opinions about the difficulty of listening to spoken English texts are at normal levels (3.29). This indicates that students are not too concerned with the challenges they face in listening. This is slightly different from Hamouda (2013) where $76.7 \%$ of the 60 students who become the object of his research argue that listening to the English oral text is difficult.

In addition, as a result of the difficulty of listening to spoken English texts, the level of boredom of students towards listening was at normal levels (2.67). Even attempts to avoid listening courses are at a low level (1.95). In this case, the research findings are in line with Hamouda (2013) where only $25 \%$ of participants think that listening is a tedious activity. Thus, it can be said that students are less affected by the difficulties they face and feel in listening activities. This is closely related to the experience of students in learning to listen. However, this is certainly different from Adnan (2012), where the teaching of listening is sometimes neglected, and the teacher is not creative in packing teaching material to listen. In other words, it can be concluded that, students' learning to listen provides an impressive experience for students so that the motivation to follow the learning listening came up. 
Thus, there is an inconsistent relationship between students' attitudes toward the importance of listening to spoken English text that is at a very high level while students' attitudes toward difficulty in listening to spoken English texts are at normal levels. This indicates that, students are not too concerned with the challenges they face in listening even they have a high motivation in doing listening activities.

\section{Difficulties faced by students in listening to spoken English text}

This section describes the research data relating to the type of difficulty faced by students in listening to spoken English text which is the theme 2 of research data that is at a high level in which the average score is 3.52. Of the 50 items of statements in the questionnaire, there are 38 statements divided into two topics, namely (1) internal issues that include (a) matter, (b) language, (c) concentration, (d) psychological aspects, and (e) student listening skills, and (2) external problems that include (a) the speaker, and (b) the physical or environmental aspects. This exposure is based on the average of each topic in theme 2 presented in Diagram 3.

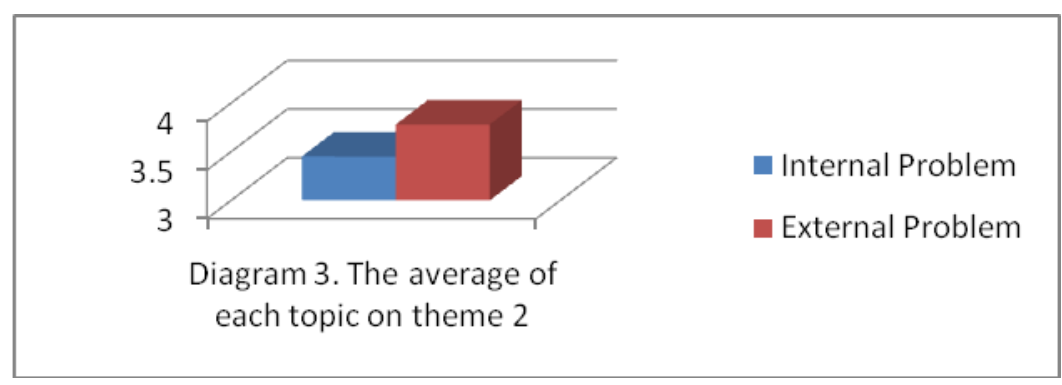

Diagram 3. The average of each topic on theme 2

Based on Diagram 3, it can be seen that the effect of internal problems that become difficulties faced by students in listening comprehension is at a high level in which the average is at number 3.45. Meanwhile, the influence of external problems that become difficulties faced by students in listening comprehension is at a very high level in which the average is at number 3.78.

Furthermore, internal problems in listening comprehension includes concentration (average 3.79), teaching materials (average 3.59), and students' listening skills (average of 3.44) are at a high level. Meanwhile, the psychological aspects (mean 3.09) and language (mean 3.03) are at normal levels.

The first topic identifies the effect of internal problems which become the difficulties faced by the students in listening comprehension which is at a high level with the average of 3.45 . There are several aspects that fall into the internal problem. The author discusses the highest order in this aspect. The first is the concentration at the high level (3.79). Listening activities require continuous concentration, as there is no chance to repeat (Nurhidayati, 2004). This is in line with Wilson (2008) and Hermawan (2012). In addition, if the listener is worried or disturbed and unable to concentrate, it can affect the listener to understand accurately what has been observed (Bloomfield, Wayland, Rhoades, Blodgett, Linck, \& Ross, 2011). Of course, the quality of one's understanding in listening is influenced by the concentration in listening.

There are some things that affect concentration, that is, the first is poor sound quality (4.38) which is at very high level. $69.3 \%$ of 60 students agree that sound quality can interfere with concentration in listening (Hamouda, 2013). Recorded material that is less clean, or from a poor audio device will cause other difficulties for students (Case, 2012 quoted in Adnan, 2014). Poor audio quality will certainly disrupt the concentration of students in listening due to student discomfort caused by the quality of the bad audio. Obviously, 
this shows that teaching facilities have a role in determining the success of students in learning. This is in line with Nurhidayati (2004) where the quality of facilities and teaching media is one aspect that becomes difficult in listening.

The second thing that affects the concentration is when hearing a new word in the English spoken text is listened (3.76) which is at high level. When a listener has limited ability in vocabulary, grammar and other linguistic elements, this will make it difficult for the listener to understand spoken language (Adnan, 2012). In addition, Nurhidayati (2004) argues that the linguistic aspect that causes the most difficulty in listening is the aspect of vocabulary limitations. Thus, the limitations of vocabulary can affect the concentration of students in listening.

The third thing that affects the concentration is the long spoken text (3.72) that is at very high level. The length of the notion of an oral text is one of the main difficulties for listeners because they can lose focus on listening due to having to listen to long texts (Hamouda, 2013). According to Gilakjani and Ahmadi (2011), if an oral text is too long, it would be better if the text is broken down into shorter text by dividing it into shorter parts or pause it.

The fourth thing that affects the concentration is to think of the right answer (3.67) which is at a high level. $70 \%$ of the 60 students stated that once they had the answer to the questions that surrounded the text, they also tended to lose concentration in listening (Hamouda, 2013).

The fifth thing that affects the concentration is thinking of the possibility of the next question (3.41) which is at a high level. This is also in line with Hamouda (2013) which revealed that $71.7 \%$ of 60 students feel that when thinking of questions that may be asked.

From the above explanation, it can be pointed out that five things can influence the aspect of concentration in listening, namely (1) thinking of the right answer, (2) thinking about the possibility of the next question, (3) listening to the long spoken English text, (4) hearing a new word in spoken Englishspoken text, and (5) poor sound quality at high levels, so that both the teacher and the student should pay more attention to these things.

The second internal aspect that becomes the difficulties faced by the students in listening comprehension is the ability to understand teaching materials (3.59) which are at a high level. Teaching material is one of the difficulty factors in listening because it involves several things, including new vocabulary, complex sentence structure, and the length of oral text (Hamouda, 2013). One effort to overcome this is to activate students' schemata so that students can predict the listening material that will be heard (Adnan, 2012). This can be applied at the pre-teaching stage (Wilson, 2008).

There are three subjects on internal issues related to teaching materials, namely the first, length of English oral text (3.83) which is at a high level. Students argue that a long spoken English text is difficult to understand because they have difficulty in interpreting meaning, as well as in understanding complex and lengthy sentences. In line with Hamouda (2013) which suggests that $83.3 \%$ of 60 students stated that the length of oral text is a major obstacle for students to understand the text. This is in line with Hasan (2000) which states that the length of the oral text makes students bored and interferes with their concentration in listening. In other words, the length of the spoken text affects the students' understanding of listening.

The second thing is the problem with the existence of a new vocabulary (3.59) which is at a high level. This is in line with Hamouda (2013) where $85 \%$ of the 60 students stated that the new vocabulary that includes jargon and idioms becomes one of the revelations in listening. In line with that, Butt, Sharif, and Naseer-ud-Din (2010) and Hanoi (2010) quoted in Hamouda (2013) state that the main obstacle in listening is too many words that are not understood. This is in accordance with Hasan (2000) that the 
lack of vocabulary is a major obstacle for most students in listening. Thus, given the essence of the vocabulary, the teacher should be able to introduce vocabularies that may be considered new to the student before the listening activity takes place.

The third is the problem with the topics used in spoken English text (3.10) at normal levels. In this case, the student states that a new topic will be more difficult to understand. In line with Hamouda (2013) which identifies that $88.4 \%$ of 60 students think that students are keen on listening, when the topic used in oral text is a new topic. Of course, the introduction of a topic relates to the level of understanding of students in listening. This is also in line with Wilson (2008) which states that students' ignorance of the topic affects listening activities and the results. In this regard, in relation to the teaching materials used, the teacher should make a good introduction to the topic or vocabulary contained in the oral text to be presented to the student, so that this difficulty can be overcome.

Furthermore, the third aspect of internal issues is the students' listening skill which is at a high level (3.44). Good listening skills are an important component of communication (Adnan, 2012). This is because listening comprehension is the various processes of understanding and making sense of spoken language which involve knowing speechsounds, comprehending the meaning of individual words, and understanding the syntax of sentences (Nadig, 2013).

There are several things related to students' listening skills. First, the mastery of English vocabulary (3.65) is at a high level. In this case, students find it difficult to understand every word they hear, understand new vocabulary, and guess the word being heard. In line with the findings that the existence of new vocabulary is able to inhibit the students in understanding oral text, so the students also argue that mastery of English language vocabulary becomes important to note.
Secondly, the availability of audio transcripts (3.50) is at a high level. Vandergrift (2004) and Walker (2014) indicated that oral passages exist in real time and should be processed rapidly and when the passage is over, only a mental representation remains. Here, it implies that the listener is required to understand every word hears, not the one read. Audio transcripts tend to familiarize the students to focus on writing, not to speakers. No audio transcript availability. This is similar to Nunan (2008) which states that media that can be used in helping listeners understand messages delivered like images, diagrams, or other visual media. However, it does not include audio transcripts.

Third, the inability to guess what will be discussed (3.22) is at normal level. This is in line with Hamouda (2013) where $63.3 \%$ of the 60 students find it difficult to understand the meaning of every word in the text that is being listened to. Butt et al. (2010) add that trying to understand and listen to foreignlanguage texts at the same time is impossible. This shows that the difficulties not only come from listening activities, but also about what and how the student listened to the oral text.

Fourth, the inability to gain an understanding of English oral text at the first occasion (average 3.21). Of course, in listening activities, there is no chance to repeat (Nurhidayati, 2004). This indicates that on the first occasion listening, students should understand the oral text used. Although, in practice, teachers always provide the opportunity to replay the spoken text used.

Fifth, the ability to remember (3.16) is at normal level. Limitations of memory cause students to face difficulty in recalling the details of the texts being reviewed (Nurhidayati, 2004). Meanwhile, in listening, students are required to remember every detail or important information in spoken text that is heard. Obviously, this makes it another difficulty in listening.

Sixth, the questions asked about the spoken English spoken text (3.05) are at 
normal levels. In this case, students have difficulty in answering any questions raised about the spoken English text they have seen.

Meanwhile, the fourth aspect of internal problems is the psychological aspect which is at normal level (3.09). When a person feels nervous or worried, then he cannot concentrate, as well as when someone feels uncomfortable, then the ability to listen will decrease (Hamouda, 2013). In other words, the psychological aspect also contributed to the success of the process of listening. There are several things related to the psychological aspect. The first is the lack of interest in spoken English-language spoken text at a high level (3.43). In this case, students have difficulty understanding spoken English texts. Lack of interest in learning will certainly lead to boredom. This boredom is a factor inhibiting the listening, because, when the sense of boredom appears the concentration of students in listening down (Hamouda, 2013). Thus, how important the selection of teaching resources in the continuity of the learning process listening is.

The second thing is students' uncertainty about the ability to understand spoken English text on student difficulties in listening comprehension at normal levels (2.98). In this case, before the listening activities take place, students feel that they will not be able to understand the spoken English text, so there is a sense of worry that they will not be able to understand the text. This sense of worry triggers student desperation, because students can choose not to continue their listening activities. So, even with Hamouda (2013) which says that $41.7 \%$ of the 60 students are in doubt and worried about their ability to listen.

The last aspect of the internal problem is the aspect of language that is at normal level (3.03). In relation to the linguistic aspect, students have difficulty in comprehending the reduced word (3.21), the use of conjunction (3.03), and everyday language and the use of slang (2.86) are at normal levels. In relation to linguistic aspects, this can be a revelation for non-native speakers in understanding oral texts (Hamouda, 2013).

Thus, it can be concluded that the internal problem in listening comprehension was influenced by (1) concentration (3.79) which includes poor audio quality (4.38), new vocabulary (3.76), long spoken text (3.72), thinking of appropriate answers (3.67), and consider the possibility of the next question (3.41); (2) teaching material (3.59) which includes the length of the spoken English text (3.83), problems relating to the existence of new vocabulary (3.59), and topic selection (3.10); (3) students' listening skill (3.44), which includes the mastery of English vocabulary (3.65), the availability of audio transcripts (3.50), inability to guess what will be discussed (3.22), inability to gain an understanding of spoken English text at the first opportunity (3.21), ability to remember (3.16), and unable to answer questions raised about spoken English spoken text (3.05); (4) psychological aspects (3.09) which include a lack of interest in spoken English-spoken text (3.43), students' self-confidence in the ability to understand oral spoken English (2.98); and (5) language (3.03) which includes the comprehension of reduced words (3.21), use of conjunctions (3.03), colloquial and slang languages (2.86).

External problems that become student difficulties in listening comprehension include: that the physical /environmental aspects are at very high level with the average of 4.21 , while the speaker aspect is at a high level with the average of 3.66.

The first aspect of external related issues is the physical and environmental aspects, in which the effect on listening comprehension is at a very high level with a mean of 4.21. Facilities and teaching media can influence how students understand the texts they hear. Bloomfield, et al. (2011) state that audio noise or clarity is related to students' understanding of listening.

The first thing related to this problem is the audio quality that is at very high level (4.40). Poor audio quality affects the 
students' understanding of listening to spoken English text. Hamouda (2013) revealed that the majority of students have difficulty in listening when the audio quality is playing bad. This may be because the audio or cassette used has been used for a long time.

The second thing is the environmental factor (4.02) which is at a high level. Students have difficulty in understanding spoken English text if the surroundings are noisy. Noise can come from outside the classroom or in the classroom, where students think the noise interferes with their activity in listening. Hamouda (2013) revealed that $96.9 \%$ of the 60 students have difficulty concentrating in listening because the circumstances at the glance of the keys are noisy. Of course, if the noise cannot be reduced, it will negatively affect the students' understanding of listening.

Furthermore, the second aspect of the external problem involved is the aspect of the speaker, which effect on listening comprehension is at a high level with a mean of 3.66. This problem is related to speaker style, pronunciation, speech, and sound heard without seeing the speaker directly (Hamouda, 2013). This is also reinforced by Yagang (1993) who states that listening ability is the ability to identify and understand what others are talking about, including the understanding of the speaker's accent, the spelling, the grammar, and the vocabulary used, and the understanding of meaning at the same time.

The first thing that appears in the research data is the aspect of pronounced speech speech (4.09) which is at a high level. Students have difficulty in listening when the speaker pronunciation is unclear. Hamouda (2013) revealed that $36.7 \%$ of 60 students have difficulty in understanding a word whose pronunciation is less clearly heard.

The second thing is the chance of repeating audio playback (4.05) which is at a high level. Students have difficulty understanding oral English text if they are given only one-time listening. This is also in line with aspects in understanding teaching materials, where students have difficulty in understanding an oral text in the first opportunity to listen to the text. This is because listeners cannot always ask speakers to repeat what they have to say (Nurhidayati, 2004; Hamouda, 2013). Moreover, 75\% of 60 students have difficulties to understand the material if not given the opportunity to repeat the playback of the text (Hamouda, 2013). This is certainly a serious problem, where in the learning process, whether or not the audio is repeated certainly based on the consideration of the teacher. The teacher decides the purpose and the right time to play back the audio, even though the teacher himself cannot ascertain in which part the student has not understood (Underwood, 1990).

The third thing is the speed of speech (3.98) which is at a high level. Students have difficulty in understanding spoken English text when speakers speak too fast. High speaking speed certainly affects the understanding of the meaning being said. $90 \%$ of the 60 students thought that when the speaker had high speech speeds, the students had difficulty understanding what the speaker was saying even if the students were familiar with the word being said (Hamouda, 2013). Thus, students certainly have difficulty when listening to speech from speakers who have high speaking speed (Underwood, 1990). This is in line with Flowerdew \& Miller (1992) and Hayati (2010) who identify that speech speed is the biggest obstacle in the process of understanding a text.

The fourth is the pause of speech (3.95), which is at a high level. Students have difficulty understanding spoken English text when the speaker does not pause the conversation. Pause is another factor that inhibits the understanding of the listeners. Hamouda revealed that $83.7 \%$ of 60 students have difficulty in understanding an utterance when the speaker does not give a pause in the conversation. Pause in talk will give the opportunity to the listener to think. In addition, pause in speech also provides an 
opportunity for listeners to understand speech (Yousif, 2006) and provides them with the opportunity to record (Dunkel, 1988) in accordance with the quotation in Hamouda (2013).

The fifth is a speech accent (3.62) which is at a high level. Students have difficulties in understanding spoken English text when the speaker has a different accent. Based on Hamouda (2013), 73.3\% of the 60 students have difficulty in listening when the speaker has a different accent. This is because students are not accustomed to hearing various accents of speech.

The sixth aspect is the smoothness of speech (3.31) which is at normal level. Students find it difficult to understand spoken English texts in which the speaker is hesitant or there are many pauses in speech. A natural conversation certainly contains hesitation, speech pause and speech intonation. $70 \%$ of 60 college students have difficulty understanding a conversation that has many doubts in speech or a lot of lag (Hamouda, 2013). This is also in line with Hasan (2000) who states that the hesitations and pause in speech are obstacles for nonnative speakers in understanding an utterance. Thus, Harmer (2001) suggests for teachers to train students with different types of oral text, which contain redundancy, doubt, and irregular grammar.
The last thing is the visual aid (2.62) which is at normal levels. Students have difficulty in understanding oral English text without seeing the speaker's gestures. Hamouda (2013) suggests that $90 \%$ of the 60 students have difficulty in understanding the text regardless of the gestures of the speaker. Of course, gestures and mimics of the speaker will help the listener in understanding the texts being uttered. Thus, visual aids, whether in the form of images, photos, or videos help students understand oral text.

Based on the discussion, it can be argued that the physical and environmental aspects affect the listening process, which is caused by the audio quality (4.40) and ambient noise (4.02). While the speaker aspect influences the students in listening to include several aspects, namely the pronunciation aspect of fluent speech (4.09), the chance of repeating audio playback (4.05), speaking speed (3.98), speech pause (3.95), speaking accent (3.62), and visual aids (2.62).

\section{Students' efforts in improving their} ability in listening to Spoken English texts This section describes research data relating to the students' efforts in improving their listening skill in listening to spoken English text which is the theme 3 of research data at a high level with a mean of 3.74 .

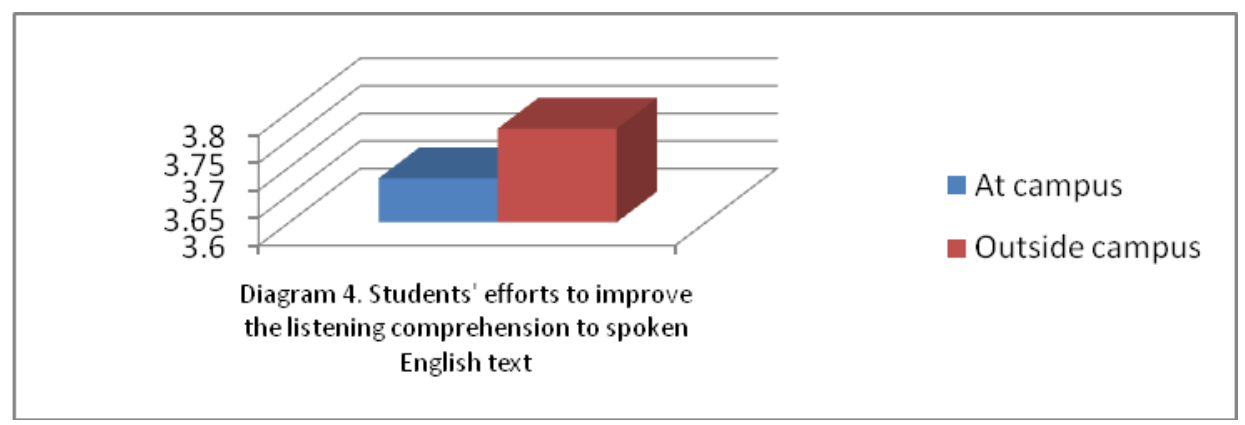

Diagram 4. Students' efforts to improve listening comprehension

Based on Diagram 4, it can be seen that the efforts undertaken by students are at a high level with the average of 3.77 for efforts made outside the campus, and the average of 3.68 for the efforts made on campus. Students' efforts in improving their listening skill in listening to spoken English text done on campus are at a high level with a mean of 3.68. This includes listening to every English utterance of lecturers or friends who are speaking as an effort to improve their listening skill in listening to spoken English text at a high level with a mean of 4.05. This is in line with Hamouda 
(2013) who identified that $66.7 \%$ of 60 students practice their listening skills by communicating with both teachers and friends on campus. While the effort made by the students by attending special training to listen comprehensively the English oral text is at normal level with the average of 3.31.

The second topic is the efforts of students in improving their listening skill in listening to spoken English text conducted outside the campus at a high level with a mean of 3.77. This effort includes listening to English-language songs that is at very high levels (4.57); watching non-text English video is at high level (4.00); elearning via cassette or CD is at normal level (3.38); and listening to foreign radio channel (3.14) is at normal level. Thus, the students did efforts to improve their listening skill in listening to spoken English text, both oncampus and off-campus.

\section{CONCLUSION}

Based on the results of the discussion, it is known that students are addressing listening comprehension as important to learn, so they are happy and will learn to listen to the spoken English text comprehensively to improve their listening skill. In addition, due to difficulties in listening comprehension, students are not too concerned with the challenges they face in listening. In other words, it can be said that students are less affected by the difficulties they face and feel in listening activities. Of course, this is closely related to the experience of students in learning to listen.

Thus, there is an inconsistent relationship between students' attitudes toward the importance of listening to spoken English text that is at a very high level while students' attitudes toward difficulty in listening to spoken English texts are at normal levels. This indicates that students are not too concerned with the challenges they face in listening even they have a high motivation in doing listening activities.

In addition, with regard to efforts made by students in improving their listening skills, students showed a high attitude. This indicates that there are efforts made by students to improve their listening skill both on and off campus. Based on the results of exposure, the most high effort done by the students is to listen to English songs, followed by watching videos in English without text. This is certainly worth doing considering these two things are fun. Of course, with the pleasure of doing something, then the benefits of these activities will be more leverage.

Students' efforts in improving their listening skill in listening to spoken English text done on campus are at a high level with a mean of 3.68. This includes listening to every English utterance of lecturers or friends who are speaking as an effort to improve the ability to listen to spoken English text at a high level with a mean of 4.05. This is in line with Hamouda (2013) who identified that $66.7 \%$ of 60 students practice their listening skills by communicating with both teachers and friends on campus. While the effort made by the students by attending special training to listen comprehensively the English oral text is at normal level with the average of 3.31.

The second topic is the efforts of students in improving their listening skill in listening to spoken English text conducted outside the campus at a high level with a mean of 3.77. This effort includes listening to English-language songs that are at very high levels (4.57). Watching English nontext video is at high level (4.00); e-learning via cassette or CD is at normal level (3.38); and listening to foreign radio channel (3.14) is at normal level. Thus, the students' efforts in improving their listening skill to listen to spoken English text is at a high level. This have been done, not only on campus, but also off-campus.

\section{ACKNOWLEDGEMENT}

This paper would not have come into existence without significant contribution from so many stakeholders. Therefore, in this opportunity, I would like to express my gratitude and deep appreciation for those who have helped and supported me in 
writing this paper. My first and foremost thanks go to LPPM Universitas of Kuningan as funding supporter of my paper. I would like also to thank all participants involved in my study for their willingness and kindly without which I would not able to finish my research. My special thanks are also due to my co-author, Afifah Husnul Badriah, for her help in composing the paper.

I am also so grateful to my husband, Brigadir Fajar Gumilang, SH., my beloved sons, Muhammad Abidzar Bani Akbar and Muhammad Arsy Al-Ghiffari, as well as my lovely daughter, Azahra Linggar Aulia, as my spirit and inspiration of life for their kindness, willingness and support in finishing this paper.

\section{REFERENCES}

Adnan, A. (2012). Pengajaran menyimak bahasa Inggris: Masalah dan solusinya. Lingua Didaktika, 6(1), 1-9.

Bloomfield, A., Wayland, S. C., Rhoades, E., Blodgett, A., Linck, J., \& Ross, S. (2011). What makes listening difficult?: Factors affecting second language listening comprehension. International Journal of Academic Research in Progressive Education and Development, 2(2).

Butt, M. N., Sharif, M. M., \& Naseer-ud-Din. (2010). Listening comprehension problems among the students: A case study of three govt. boys' higher secondary schools. European Journal of Social Sciences, 18(2).

Cresswell, J. W. (2014). Research design: Qualitative, quantitative and mix methods approaches. New Delhi: Sage.

Gall, M. D., Borg, W. R., \& Gall, J. P. (2003). Educational research: An introduction (7th ed.). Boston: Pearson.

Gilakjani, A. P. \& Ahmadi, M. R. (2011). A study of factors affecting EFL learners' English listening comprehension and the strategies for improvement. Journal of Language Teaching and Research, 2(5), 977-988.

Goh, C. (2000). A cognitive perspective on language learners' listening comprehension problems. System, 28, 55-75.

Hamouda, A. (2013). An investigation of listening comprehension problems encountered by Saudi students in the EL listening classroom. International Journal of Academic Research in Progressive Education and Development, 2(2).
Hasan, A. (2000). Learners' perceptions of listening comprehension problems. Language, Culture and Curriculum, 13, 137-152.

Harmer, J. (2001). The practice of English language teaching. Essex, England: Longman.

Hayati, A. (2010). The effect of speech rate on listening comprehension of EFL learners. Creative Education, 2, 107-114. doi:10.4236/ce.2010.12016.

Hermawan, H. (2012). Menyimak keterampilan berkomunikasi yang terabaikan. Yogyakarta: Graha Ilmu.

Jafari, K., \& Hashim, F. (2015). A comparison of normal and moderately slow speech rates: Listening to students' voices in listening comprehension classes in EFL context. International Journal of Foreign Language Teaching in the Islamic World (FLTJ), 3(3), 511.

Malik, R. S., \& Hamied, F. A. (2014). Research methods. Bandung: UPI Press.

Muljanto, S. (2012). Analysis of barriers in listening comprehension among junior high school students. English Review: Journal of English Education, 1(1), 78-85.

Nunan, D. (2008). Practical English language teaching: Reading . New York: McGraw Hill.

Nurhidayati. (2004). Jenis dan sebab kesulitan yang dihadapi oleh mahasiswa dalam menyimak teks bahasa. Bahasa dan Seni, 32(1).

Osada, N. (2004). Listening comprehension research: A brief review of the last thirty years. Japan: TALK.

Oskamp, S., \& Schultz, P. W. (2005). Attitudes and opinion ( $3^{\text {rd }}$ Ed.). London: Lawrence Erlbaum Associates.

Rost, M. (2002). Teaching and researching listening. London: Longman.

Sugiyono. (2012). Metode penelitian kuantitatif, kualitatif dan $R \& D$. Bandung: Alfabeta.

Thomas, I., \& Dyer, B. (2007). The problem of poor listening skills. Retrieved from: http/ faculty.weber.edu/.

Vandergrift, L. (2004). Listening to learn or learning to listen? In Cambridge University Press (Ed.), Annual Review of Applied Linguistics (pp. 325). Cambridge: Cambridge University Press, USA.

Wallace, C. S., Hand, B. B., \& Prain, V. (2004). Writing and learning in the science classroom. Netherlands: Springer.

Walker, N. (2014). Listening: The most difficult skill to teach. Encuentro, 23, 167-175.

Wilson, J. J. (2008). How to teach listening. Edinburgh: Pearson Longman Limited. 


\section{Vina Agustiana}

Listening anxiety among Indonesian EFL students 